\title{
ガラス前駆体化学増幅レジスト (GPR)
}

Chemically Amplified Glass Precursor Resist

スピンオングラス（SOG）は簡便にケイ酸ガラス系 薄膜を得る方法として Si-LSI プロセスにおいて注目 されている，高融点金属を用いた配線加工のための工 ッチングマスク [1], 多層レジスト法 [2] の中間膜, 層間絶縁膜 [3], さらには位相シフト露光法 [4] の シフタ材料などとして使われるようになった。一般に は耐クラック性や塗布性の点から有機系 SOG が用い られる場合が多い. 市販の有機系 SOG の正確な構造 は不明であるが，シラノールを一部アルキル基によっ てエーテル化したものである. 成膜後, $200^{\circ} \mathrm{C}$ 以上で 焼成してケイ酸ガラス類似の薄膜とするが，膜中には 有機基が若干残存する。

化学増幅ガラス前駆体レジスト (Glass precursor resist, GPR) [5] はケイ酸ガラス前駆体ポリマーと 酸発生㓮の二成分よりなり, 電子線および紫外線に対 し高い感度を有するネガ型レジストとして機能する。 また得られたパターンが完全な $\mathrm{SiO}_{2}$ 膜となる感光性 の SOGでもある.ケイ酸ガラス前駆体ポリマーとし てはポリ（ジー $t$-ブトキシシロキサン）を, 酸発生剤 としてはスルホニウム塩を用いている。このレジスト 膜に電子線や紫外線を照射すると, 酸発生剂が分解し て酸が発生し，これが触媒となって図 1 に示した反応 が起こる. 即ちポリマー側鎖の $t$-ブチル基が脱離, 生成したシラノールポリマー中間体は直ちに縮合して ケイ酸ガラスと同等な構造を有する無機ポリマーに変 換される.

GPR のケイ酸ガラス化は, 実際にパターン形成に 必要な露光量による露光と $100^{\circ} \mathrm{C}$ 程度の露光後加熱に

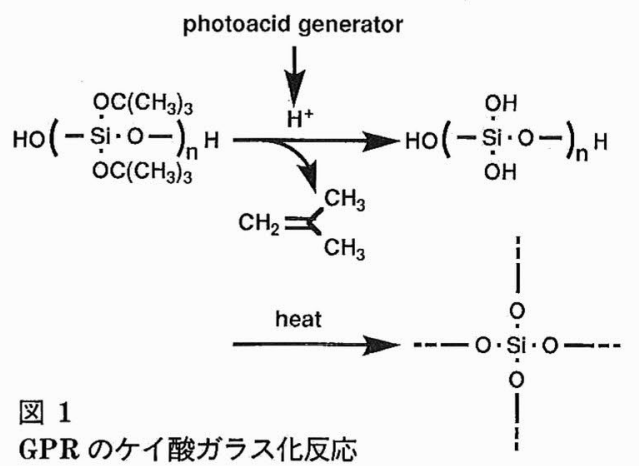

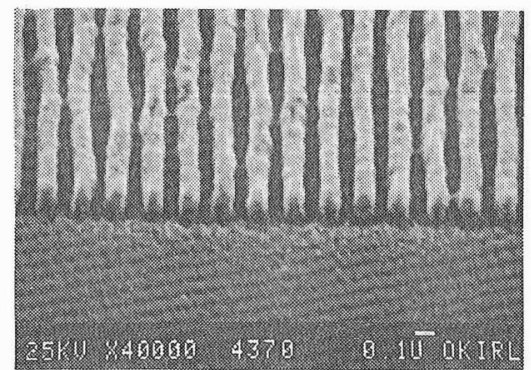

露光量 $3.7 \mu \mathrm{C} / \mathrm{cm}^{2}$

図 2 GPR の $0.1 \mu \mathrm{m}$ パターン

よって達成される。露光した膜は IR スペクトルにお いて $\mathrm{C}-\mathrm{H}$ 伸縮振動の吸収が完全に消失しており，ケ 洒夋ガラスに変換されていることが分かった。変換さ れた膜は, CVD (化学的気相成長) 法により形成した NSG (ノンドープシリカガラス) 膜と酷似しているこ とも分かった。電子線レジストとしての感度は 1.7 $\mu \mathrm{C} / \mathrm{cm}^{2}$ であり, 解像度は $0.1 \mu \mathrm{m}$ 以下である. 図 2 に GPR の $0.1 \mu \mathrm{m}$ ラインアンドスペースパターンを 示す.

酸素プラズマに対する耐性は，多層レジストに用い られる下層用熱硬化樹脂のおよそ 110 倍である。また GPR パターンを直接形成の酸化膜マスクとして用い たタングステンのエッチングでは塩素/酸素混合ガス を用いたドライエッチングで選択比 10 程度が得られ， NSG 膜とほぼ同等の値が得られた。

\section{文 献}

1) K. Ohno, M. Sato, Y. Arita : Jpn. J. Appl. Phys., 28 (1989) 1070

2) J.M. Moran, D. Maydan: J. Vac. Sci. Technol., 19 (1981) 946

3) S. Ito, Y. Homma, E. Sasaki, S. Uchimura, H. Morishima : Extended Abstract of 20th Conference on Solid State Devices and Materials, Tokyo, 1988, p. 609

4) M.D. Levenson: IEEE Trans. on Electron Devices, ED-29, 12 (1982)

5) M. Sakata, T. Ito, M. Kosuge, Y. Yamashita: $J$. Photopolym. Sci. Technol., 5 (1992) 181

(沖電気工業 (株) 半導体技術研究所 - 主任研究員, 理博，専門=有機合成，レジス卜材料） 